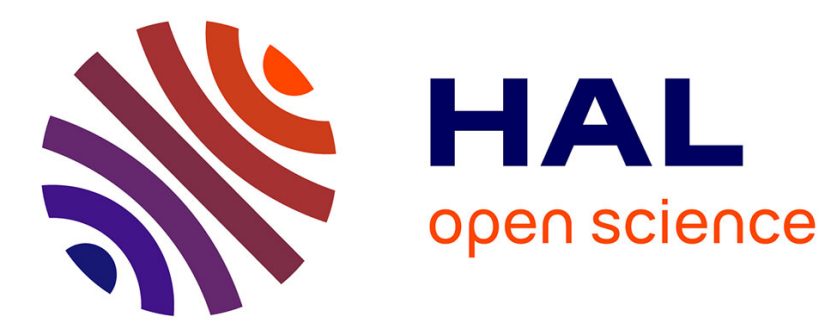

\title{
O 095-How do postural parameters vary during gait in children with cerebral palsy? A 3D subject-specific skeletal segment registration technique
}

Abir Massaad, Ayman Assi, Aren Joe Bizdikian, Ziad Bakouny, Nour Khalil, Ismat Ghanem, Hélène Pillet, Xavier Bonnet, Wafa Skalli

\section{To cite this version:}

Abir Massaad, Ayman Assi, Aren Joe Bizdikian, Ziad Bakouny, Nour Khalil, et al.. O 095-How do postural parameters vary during gait in children with cerebral palsy? A 3D subject-specific skeletal segment registration technique. Gait \& Posture, 2018, 65, pp.1-3. 10.1016/j.gaitpost.2018.06.130 . hal-02891924

\section{HAL Id: hal-02891924 \\ https://hal.science/hal-02891924}

Submitted on 7 Jul 2020

HAL is a multi-disciplinary open access archive for the deposit and dissemination of scientific research documents, whether they are published or not. The documents may come from teaching and research institutions in France or abroad, or from public or private research centers.
L'archive ouverte pluridisciplinaire HAL, est destinée au dépôt et à la diffusion de documents scientifiques de niveau recherche, publiés ou non, émanant des établissements d'enseignement et de recherche français ou étrangers, des laboratoires publics ou privés. 


\title{
O 095-How do postural parameters vary during gait in children with cerebral palsy? A 3D subject-specific skeletal segment registration technique
}

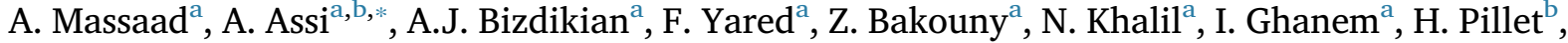 \\ X. Bonnet ${ }^{\mathrm{b}}$, W. Skalli ${ }^{\mathrm{b}}$
}

a Faculty of Medicine-University of Saint-Joseph, Laboratory of Biomechanics and Medical Imaging, Beirut, Lebanon
${ }^{\mathbf{b}}$ Arts et Métiers ParisTech, Institut de Biomécanique Humaine Georges Charpak, Paris, France

\author{
Keywords: \\ Cerebral Palsy \\ Typically developing children \\ Gait analysis \\ EOS \\ Image registration technique \\ Acetabulum \\ Pelvis
}

\section{Introduction}

Postural parameters, calculated in static position on frontal and sagittal radiographs, are altered in ambulant children with cerebral palsy (CP) and are known to be related to gait abnormalities [1,2]. Most of these parameters are positional and could vary during gait. Their computation could be performed using gait simulation models that are usually generic or semi-personalized [2,3]. There are currently no studies investigating how subject-specific postural parameters are modified during gait in children with CP.

\section{Research Question}

How do postural parameters vary during gait in children with CP?

\section{Methods}

14 typically developing children (TD-group, age:11.7 \pm 4 year) and 14 children with cerebral palsy (CP-group, age:11 \pm 4 year, Hemiplegia: $N=4$, Diplegia: $N=10$ ) underwent gait analysis using Davis protocol [3] with additional markers on thighs and shanks. Subjects then underwent low-dose biplanar X-rays in standing position with the reflective markers still in place. Subject-specific 3D reconstruction of the spine, pelvis and lower limbs were performed with calculation of 3D radiological postural parameters in the static position: pelvic tilt(PT), sacral slope(SS), acetabular abduction(Acetabular_Abduction), anteversion(Acetabular_Anteversion) and tilt(Acetabular_Tilt) [4] as well as anterior (Ant_Acet_coverage) and posterior (Post_Acet_Coverage) acetabular coverage over the femoral head. 3D bones were registered on each frame of the gait cycle [5] (Fig. 1). A new technique developed for this study, utilizing finite element modeling, was used to reduce soft tissue artefacts. The same postural parameters were then computed during the gait cycle, using the 3D registered bones, at each time frame: means and ranges of motion (ROM) were calculated then compared between TD and CP.

\section{Results}

The TD-group had an Acetabular_Anteversion of $14 \pm 5^{\circ}$ (CPgroup: $12.5 \pm 4^{\circ}$ ) in static position that increased to an average of $18 \pm 4^{\circ}$ during gait only in the TD-group ( $\mathrm{p}<0.001$ ). During walking, the average over the entire gait cycle of the Acetabular_Anteversion and Acetabular_Tilt was decreased in the CPgroup (Acetabular_Anteversion: CP: $13 \pm 6^{\circ}$ vs TD:18 $\pm 4^{\circ}$, $\mathrm{p}=0.001$; Acetabular_Tilt: CP: $20 \pm 8^{\circ}$ vs TD: $25 \pm 6^{\circ}$; $\mathrm{p}=0.011$, Figs. $2 \& 3$ ). Moreover, the average of SS during gait was increased in the CP-group when compared to TD (44 $\pm 6^{\circ}$ vs. $\left.34 \pm 8^{\circ}, \mathrm{p}=0.002\right)$. The ROM of the PT was significantly larger in the CP-group compared to TD (9 $\pm 3^{\circ}$ vs. $\left.6 \pm 2^{\circ}, \mathrm{p}=0.05\right)$ (Fig. 3 ).

\footnotetext{
* Corresponding author.

E-mail address: ayman.assi@usj.edu.lb (A. Assi).
} 


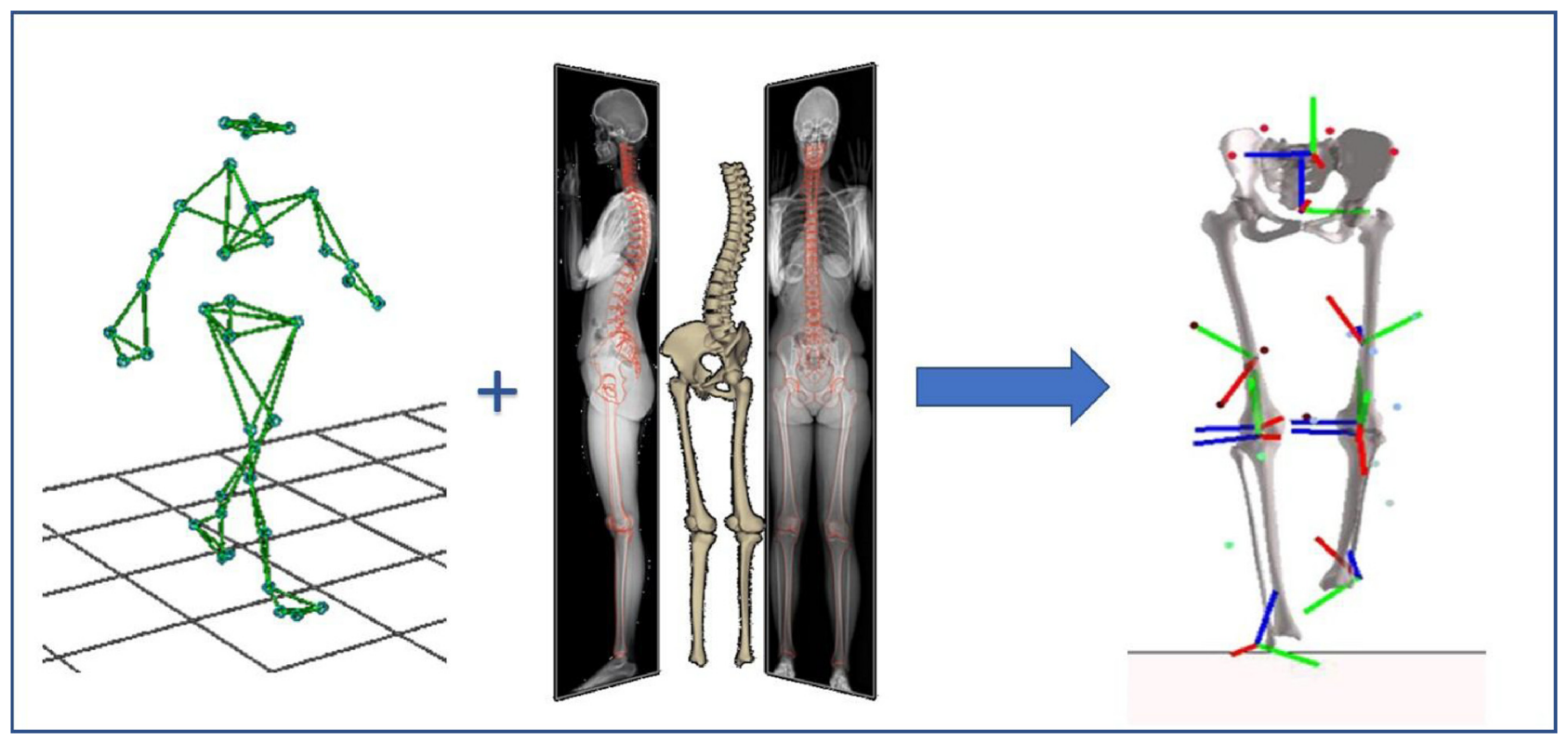

Fig. 1. Registration technique of 3D skeletal segments in gait analysis.

\section{D acetabular and pelvic parameters calculated in standing position} and during the gait cycle in CP and TD children

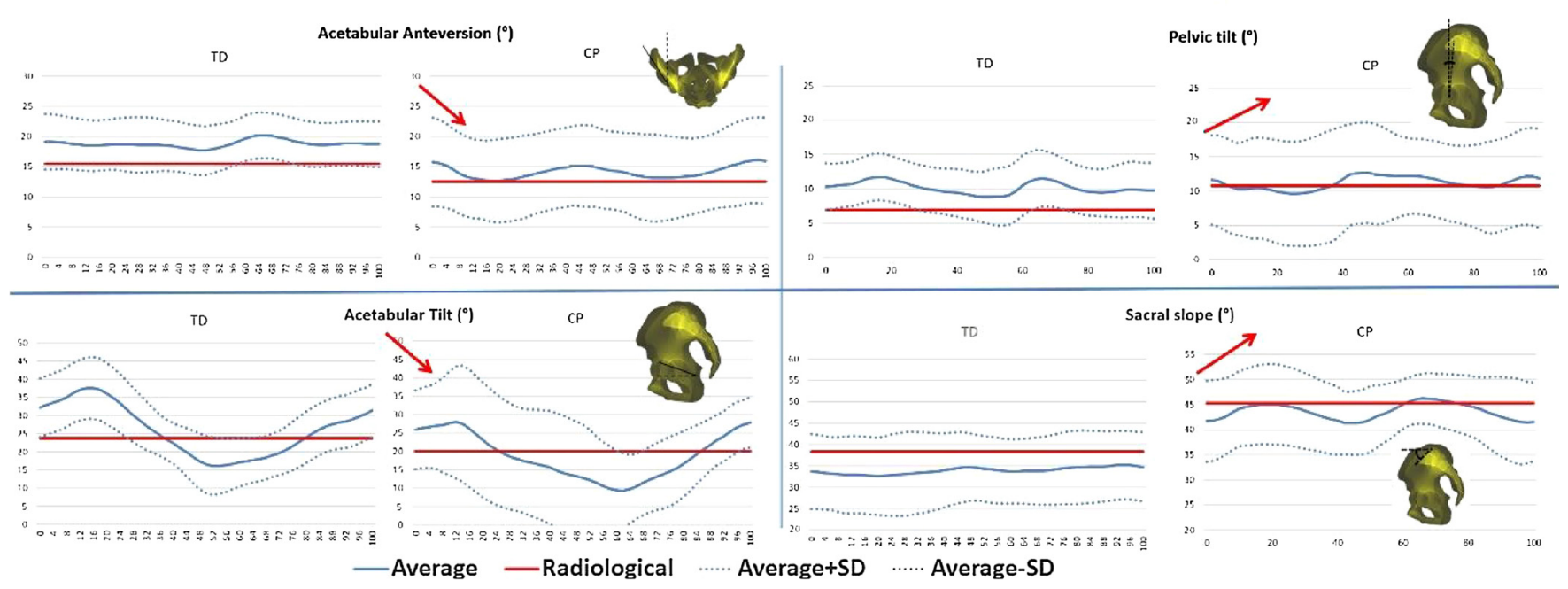

Fig. 2. 3D acetabular and pelvic parameters calculated in standing position and during the gait cycle in CP and TD children.

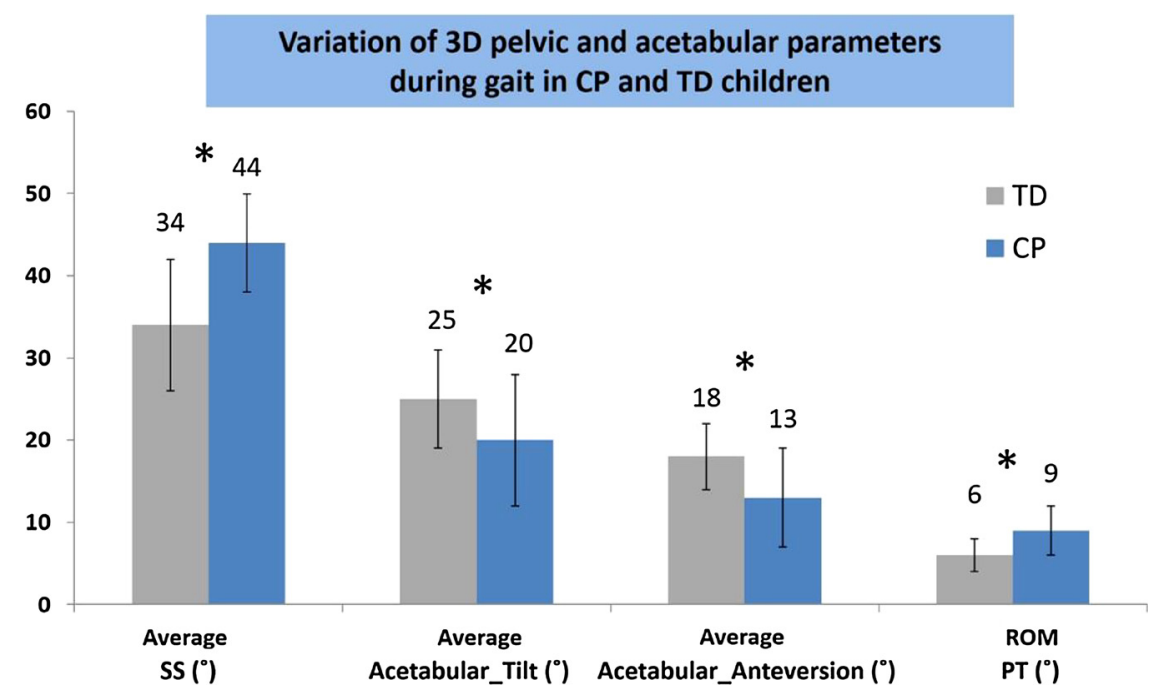

Fig. 3. Variation of 3D pelvic and acetabular parameters during gait in $\mathrm{CP}$ and TD children. 


\section{Discussion}

This is the first study to compute 3D subject-specific postural parameters during gait in children with $\mathrm{CP}$. The $\mathrm{CP}$-group presented a higher ROM of PT during walking which could be related to altered spinal movement and stability during gait. Children with CP seem to present significant acetabular alterations in static and dynamic that might alter lower limb kinematics during gait. Future studies should investigate acetabular postural parameters in patients with different gait profiles to elucidate postural and compensatory behaviors in children with CP. The subject-specific skeletal registration technique could

\section{References}

1] Massaad et al., Gait and Posture, 2016.

[2] Aktas et al., Journal of Pediatric Orthopedics, 2000.

[3] Bosman et al., Gait and Posture, 2016.

[4] Davis et al., Human Movement Science, 1991.

[5] Söderkvist et al., Human Movement Science, 1991. 